\title{
Molecular factors of 5-fluorouracil metabolism in colorectal cancer: Analysis of primary tumor and lymph node metastasis
}

\author{
D. VALLBÖHMER ${ }^{1,2}$, H. KURAMOCHI ${ }^{1}$, D. SHIMIZU ${ }^{1}$, K.D. DANENBERG ${ }^{3}$, \\ J. LINDEBJERG ${ }^{4}$, J.N. NIELSEN ${ }^{3}$, A. JAKOBSEN ${ }^{3}$ and P.V. DANENBERG ${ }^{1}$
}

\begin{abstract}
${ }^{1}$ Norris Comprehensive Cancer Center, University of Southern California, 1441 East Lake Avenue, Los Angeles, CA 90033, USA; ${ }^{2}$ Department of Surgery, University of Cologne, Joseph-Stelzmann Strasse 9, D-50924 Cologne, Germany;

${ }^{3}$ Response Genetics, Inc., 1640 Marengo Street, Los Angeles, CA 90033, USA; ${ }^{4}$ Danish Colorectal Cancer Group South, Department of Oncology, University of Southern Denmark, Vejle Hospital, Kabbeltoft 25, 7100 Vejle, Denmark
\end{abstract}

Received August 30, 2005; Acceptance October 17, 2005

\begin{abstract}
Thymidylate synthase (TS), dihydropyrimidine dehydrogenase (DPD) and thymidine phosphorylase (TP) are predictive markers for tumor response to 5-fluorouracil-based therapies. To determine whether gene expression values measured in primary cancer tissue would be useful for prediction of response of lymph node metastases, the expressions of these genes were quantitatively analyzed in 35 pairs of primary colorectal cancer (CRC) and corresponding lymph node metastases using real-time PCR. DPD and TP mRNA levels were significantly lower in the primary colorectal tumor and lymph node metastases compared with the normal adjacent stroma tissue $(\mathrm{p}<0.01)$, whereas TS mRNA levels were significantly higher in the primary tumor and lymph node metastases than in the normal adjacent tissue $(\mathrm{p}<0.001)$. Median gene expression levels of TP and TS did not differ significantly between primary colorectal tumor and corresponding lymph node metastasis but median DPD gene expression levels in the lymph node metastases were significantly higher compared to matched primary colorectal tumors $(\mathrm{p}=0.015)$. There was a significant correlation for DPD, TP and TS gene expression levels between primary colorectal tumor specimens and the matched lymph node metastasis. These results suggest that biopsies of the tumor of origin may be valid for determining predictive markers for chemotherapy response in patients with metastatic CRC.
\end{abstract}

\section{Introduction}

The study of genetic differences between primary tumors and metastases has been intensely pursued. Differential gene or

Correspondence to: Dr Peter V. Danenberg, University of Southern California/Norris Comprehensive Cancer Center, NOR 5318, 1441 East Lake Avenue, Los Angeles, CA 90033, USA

E-mail: pdanenbe@usc.edu

Key words: metastatic colorectal cancer, 5-fluorouracil, molecular determinants protein expression between a tumor and its metastases not only underlies the mechanism of tumor metastasis, but more importantly to the clinician, it may determine the efficacy of chemotherapeutic agents on the primary tumor and matched metastases. The issue of the concordance between gene expressions in the primary tumor and metastases is especially important for the implementation of pharmacogenetic strategies for predicting the efficacy of chemotherapy based on analysis of molecular determinants of response. It is well established that the presence of metastases is the main cause of death from major cancers such as colorectal cancer (CRC) and breast cancer. Yet, in many cases, the only tissue available for molecular analysis may be the original pathological biopsy of the primary tumor. If the gene/protein expression profiles of the primary tumor are largely preserved and retained in metastases, then sampling of the primary tumor may adequately predict the course of the disease after chemotherapy. On the other hand, if substantial variation occurs among marker expressions between the primary tumor and metastases, prediction of outcome may only be effective by analysis of the appropriate metastatic tissue.

In recent years, many pharmacogenetic studies have been carried out with the aim of finding determinants of response for 5-fluorouracil (5-FU) based therapy in CRC and other cancers (1). These studies have identified, among other factors, intra-tumoral thymidylate synthase (TS), thymidine phosphorylase (TP) and dihydropyrimidine dehydrogenase (DPD) as potential predictive/prognostic factors. The initial studies from our laboratory indicating an association of low TS, TP and DPD gene expressions with response of CRC to 5-FU were done using liver biopsies of metastatic colorectal cancer (2-5). Paradiso et al reported that TS protein expression in primary tumor biopsies of CRC patients receiving 5-FU based chemotherapy was also related to clinical response, time to tumor progression and overall survival (6). However, in several other studies, TS expression in the primary tumor failed to predict survival or recurrence among patients with metastatic CRC receiving 5-FU based chemotherapy (7-9). According to Aschele et al, TS protein levels in CRC metastases but not those in the primary tumors were associated with response to 5 -FU (8). These workers found that TS protein levels in 
primary CRC were overall higher than those observed in the corresponding metastases (including lymph node metastases) and did not correlate between matched pairs. Yamada et al reported TS gene expression to be higher in primary colorectal cancers than in liver metastases, whereas Backus et al showed opposite results in protein level $(10,11)$. Inokuchi et al found that primary tumor TS mRNA levels did not differ significantly from those of liver metastases of CRC, although those of DPD, orotate phosphoribosyl transferase (OPRT), TP and uridine phosphorylase (UP) were significantly higher in the liver metastases (12). Similarly, DPD gene expression levels were reported to be lower in primary cancers than in liver metastases by Shirota et al, whereas another study by Guimbaud et al found that DPD activity in liver metastases was not significantly different from that observed in primary colon tumors $(13,14)$. Marsh et al, upon finding no correlation between TS protein levels in primary colorectal tumors and lymph node metastases, pointed out the danger of predicting outcome after chemotherapy in advanced CRC from the primary tumor (15). However, the substantial discrepancies among the above-cited studies, even those involving just simple measurement of protein or mRNA levels without any attempted correlations to clinical data, give a confusing picture and suggest that it is premature to draw any conclusions regarding the relationship between gene/protein expressions of TS, TP or DPD in primary tumor and corresponding metastases.

We thought it possible that discordant results from various studies could arise in part due to inherent methodological shortcomings, e.g., in the case of immunhistochemistry (IHC), from the semi-quantitative nature of the method, antibody variability and different scoring techniques, or in the case of RT-PCR, from isolating RNA from heterogeneous specimens containing both tumor tissue and surrounding normal tissue. Thus, we re-investigated the relationship between gene expressions of the three 5-FU-specific markers TS, TP and DPD in primary CRC tissue and in the matched lymph node metastases utilizing laser-capture microdissection (LCM) to better separate tumor tissue from non-tumor tissue in specimens taken from CRC patients and real-time RT-PCR to obtain precise quantitation of gene expressions.

\section{Materials and methods}

Patients. The study included 35 patients with confirmed CRC and histopathologically proven lymph node metastases. The patients were referred to Vejle Hospital for treatment and biopsies from the primary tumor and matching lymph node metastases were obtained at the operation. The study was performed according to the Helsinki II Declaration and approved by the regional ethics committee.

Microdissection. Paraffin-embedded tumor blocks (primary tumor and lymph node metastasis) were reviewed for quality and tumor content by a pathologist. Sections (10 $\mu \mathrm{m}$ thick) were obtained from the identified areas with the highest tumor concentration. Sections were mounted on uncoated glass slides. For histology diagnosis, three representative sections, consisting of the beginning, the middle and the end of sections of the tissue were stained with H\&E by the standard method. Before microdissection, sections were deparaffinized in xylene for 10 min and hydrated with 100, 95 and finally $70 \%$ ethanol. The sections were washed in $\mathrm{H}_{2} \mathrm{O}$ for $30 \mathrm{sec}$ and then stained with nuclear fast red (NFR, American MasterTech Scientific, Inc., Lodi, CA) for $20 \mathrm{sec}$ and rinsed in $\mathrm{H}_{2} \mathrm{O}$ for $30 \mathrm{sec}$. Samples were then dehydrated with 70,95 and $100 \%$ ethanol for $30 \mathrm{sec}$ each, followed by xylene for $10 \mathrm{~min}$. The slides were completely air-dried. If the histology of the sample was homogeneous and contained $>90 \%$ tissue of interest, the specimen was dissected from the slides using a scalpel. All other sections of interest were selectively isolated by laser capture microdissection (P.A.L.M. Microsystem, Leica, Wetzlar, Germany) according to the standard procedure (16). The dissected particles of tissue were transferred to a reaction tube containing $400 \mu 1$ of RNA lysis buffer.

RNA isolation and cDNA synthesis. The tissue samples to be extracted were placed in a $0.5 \mathrm{ml}$, thin walled tube containing $400 \mu 1$ of $4 \mathrm{M}$ dithiothreitol (DTT)-GITC/sarc (4 M guanidinium isothiocyanate, $50 \mathrm{mM}$ Tris- $\mathrm{HCl}, \mathrm{pH} 7.5,25 \mathrm{mM}$ EDTA) (Invitrogen; \#15577-018). The samples were heated at $92^{\circ} \mathrm{C}$ for $30 \mathrm{~min}$ and then transferred to a $2 \mathrm{ml}$ centrifuge tube. To the tissue suspensions were added $50 \mu 1$ of $2 \mathrm{M}$ sodium acetate, pH 4.0, followed by $600 \mu 1$ of freshly prepared phenol/chloroform/isoamyl alcohol (250:50:1). The tubes were vortexed for $15 \mathrm{sec}$, placed on ice for $15 \mathrm{~min}$ and then centrifuged at $13000 \mathrm{rpm}$ for $8 \mathrm{~min}$ in a chilled $\left(8^{\circ} \mathrm{C}\right)$ centrifuge. The upper aqueous phase $(250-350 \mu 1)$ was carefully removed and placed in a $1.5 \mathrm{ml}$ centrifuge tube. Glycogen $(10 \mu \mathrm{l})$ and $300-$ $400 \mu \mathrm{l}$ of isopropanol were added and the samples vortexed for $10-15 \mathrm{sec}$. The tubes were placed at $-20^{\circ} \mathrm{C}$ for $30-45 \mathrm{~min}$ to precipitate the RNA. The samples were then centrifuged at $13000 \mathrm{rpm}$ for $7 \mathrm{~min}$ in a chilled $\left(8^{\circ} \mathrm{C}\right)$ centrifuge. The supernatant was poured off and $500 \mu 1$ of $75 \%$ ethanol was added. The tubes were centrifuged at $13000 \mathrm{rpm}$ for $6 \mathrm{~min}$ in a chilled $\left(8^{\circ} \mathrm{C}\right)$ centrifuge. The supernatant was carefully poured off so as not to disturb the RNA pellet and the samples were quickspun for $15 \mathrm{sec}$ at $13000 \mathrm{rpm}$. The remaining ethanol was removed with a $20 \mu 1$ pipette and the samples air-dried for $15 \mathrm{~min}$. The pellet was re-suspended in $50 \mu 1$ of $5 \mathrm{mM}$ Tris. cDNA was prepared as previously described (17). This is a proprietary procedure of Response Genetics, Inc. (Los Angeles, CA; United States patent number 6,248,535).

Real-time PCR quantification of mRNA expression. Quantitation of DPD, TP, TS and an internal reference gene ( $ß$-actin) was done using a fluorescence based real-time detection method [ABI PRISM 7900 Sequence detection System (TaqMan ${ }^{\circledR}$ ) Perkin-Elmer (PE) Applied Biosystem, Foster City, CA, USA] (18). The PCR reaction mixture consisted $1200 \mathrm{nM}$ of each primer, $200 \mathrm{nM}$ probe, $0.4 \mathrm{U}$ of AmpliTaq Gold Polymerase, $200 \mathrm{nM}$ each dATP, dCTP, dGTP, dTTP, $3.5 \mathrm{mM} \mathrm{MgCl}_{2}$ and $1 \mathrm{X}$ TaqMan Buffer A containing a reference dye, to a final volume of $20 \mu \mathrm{l}$ (all reagents from PE Applied Biosystems). Cycling conditions were $50^{\circ} \mathrm{C}$ for $2 \mathrm{~min}, 95^{\circ} \mathrm{C}$ for $10 \mathrm{~min}$, followed by 46 cycles at $95^{\circ} \mathrm{C}$ for $15 \mathrm{sec}$ and $60^{\circ} \mathrm{C}$ for $1 \mathrm{~min}$. The primers and probes used are listed in Table I.

Gene expression values (relative mRNA levels) are expressed as ratios (differences between the $\mathrm{Ct}$ values) between the gene of interest and an internal reference gene ( $ß$-actin) that 
Table I. Primers and probes sequences.

\begin{tabular}{lclll}
\hline Gene & $\begin{array}{c}\text { GenBank } \\
\text { accession }\end{array}$ & \multicolumn{1}{c}{$\begin{array}{c}\text { Forward primer } \\
\left(5^{\prime}-3^{\prime}\right)\end{array}$} & \multicolumn{1}{c}{$\begin{array}{c}\text { Reverse primer } \\
\left(5^{\prime}-3^{\prime}\right)\end{array}$} & \multicolumn{1}{c}{$\begin{array}{c}\text { TaqMan probe } \\
\left(5^{\prime}-3^{\prime}\right)\end{array}$} \\
\hline ß-actin & NM_001101 & GAGCGCGGCTACAGCTT & $\begin{array}{c}\text { TCCTTAATGTCACGCACGA } \\
\text { TTT }\end{array}$ & ACCACCACGGCCGAGCGG \\
DPD $^{\mathrm{a}}$ & NM_000110 & AGGACGCAAGGAGGGT & GTCCGCCGAGTCCTTACTGA & CAGTGCCTACAGTCTCGAGTCTGCCA \\
& & TTG & GTG \\
TP $^{\mathrm{b}}$ & NM_001953 & CCTGCGGACGGAATCCT & GCTGTGATGAGTGGCAGGCT & CAGCCAGAGATGTGACAGCCACCGT \\
TS $^{\mathrm{c}}$ & NM_001071 & GCCTCGGTGTGCCTTTCA & CCCGTGATGTGCGCAAT & TCGCCAGCTACGCCCTGCTCA \\
\hline
\end{tabular}

${ }^{\mathrm{a}}$ Dihydropyrimidine dehydrogenase. ${ }^{\mathrm{b}}$ Thymidine phosphorylase. ${ }^{\mathrm{c}}$ Thymidylate synthase.

Table II. Gene expression levels of dihydropyrimidine dehydrogenase, thymidine phosphorylase and thymidylate synthase in the primary tumor, matching lymph node metastasis and their adjacent normal tissue.

\begin{tabular}{|c|c|c|c|c|c|c|c|}
\hline & \multicolumn{4}{|c|}{ Primary site } & \multicolumn{3}{|c|}{ Lymph node site } \\
\hline & $\begin{array}{l}\text { Primary } \\
\text { colorectal } \\
\text { tumor }\end{array}$ & & $\begin{array}{l}\text { Normal } \\
\text { adjacent } \\
\text { stroma } \\
\text { tissue }\end{array}$ & $\begin{array}{c}\text { P-value } \\
\text { tumor vs. } \\
\text { normal adjacent } \\
\text { stroma tissue }\end{array}$ & $\begin{array}{l}\text { Lymph node } \\
\text { metastasis }\end{array}$ & $\begin{array}{l}\text { Normal } \\
\text { adjacent } \\
\text { stroma } \\
\text { tissue }\end{array}$ & $\begin{array}{c}\text { P-value } \\
\text { tumor vs. } \\
\text { normal adjacent } \\
\text { stroma tissue }\end{array}$ \\
\hline $\begin{array}{l}\mathrm{DPD}^{\mathrm{a}} \times 100 / \beta \text {-actin mRNA } \\
\text { expression median } \\
(25 \text { th- } 75 \text { th percentile })\end{array}$ & $0.34(0.25-0.45)$ & 1.01 & $(0.67-0.1 .35)$ & $<0.001$ & $0.39(0.24-0.78)$ & $1.41 \quad(0.91-1.9)$ & $<0.001$ \\
\hline $\begin{array}{l}\mathrm{TP}^{\mathrm{b}} \times 100 / \beta \text {-actin mRNA } \\
\text { expression median } \\
(25 \text { th- } 75 \text { th percentile })\end{array}$ & $1.78(1.45-2.68)$ & 3.5 & $(1.84-4.22)$ & $<0.01$ & $2.38(1.27-3.26)$ & $3.68(2.77-4.85)$ & $<0.001$ \\
\hline $\begin{array}{l}\mathrm{TS}^{\mathrm{c}} \times 100 / \mathrm{B} \text {-actin mRNA } \\
\text { expression median } \\
(25 \text { th- } 75 \text { th percentile) }\end{array}$ & $1.77(1.2-2.23)$ & 0.52 & $(0.4-0.8)$ & $<0.001$ & $1.62(0.89-2.68)$ & $0.74(0.45-1.13)$ & $<0.001$ \\
\hline
\end{tabular}

${ }^{a}$ Dihydropyrimidine dehydrogenase. ${ }^{\mathrm{b}}$ Thymidine phosphorylase. ${ }^{\mathrm{c}}$ Thymidylate synthase.

provides a normalization factor for the amount of RNA isolated from a specimen. In validating our assays, we found that gene expression values were reproducible and reliable if $\mathrm{Ct}$ values were below a certain maximum. This number varied somewhat for each gene but in general, we considered $\mathrm{Ct}$ values below 37 to be sufficiently reliable for gene expression measurements. Those gene expressions with Ct's above 37 were not reported.

Statistical analysis. DPD, TP and TS mRNA expression levels of the primary tumor and matching lymph node metastasis were compared to each other and to each normal adjacent tissue using the Wilcoxon signed-rank test. Because of the larger number of tests undertaken, the Benjamini and Hochberg multiple comparison correction was performed afterwards. The correlation between the gene expression levels of primary tumor and matching lymph node metastasis for each gene and the correlation of the genes to each other was were analyzed by using the Spearman's rank correlation. For all tests performed, statistical significance was set at the 0.05 level for the $\mathrm{p}$-value.

\section{Results}

A total of 35 patients, 21 male and 14 female (median age 68, range 47-88), were included in the study. DPD gene expression was quantifiable in $32(91 \%)$ primary colorectal tumors, in $28(80 \%)$ matching metastatic lymph nodes, in 35 (100\%) adjacent normal colon tissue samples and in $33(94 \%)$ adjacent normal lymph node tissue samples. TP gene expression was quantifiable in $34(97 \%)$ primary colorectal tumors, in $30(86 \%)$ matching metastatic lymph nodes, in 35 (100\%) adjacent normal colon tissue samples and in 33 (94\%) adjacent normal lymph node tissue samples. TS gene expression was quantifiable in $34(97 \%)$ primary colorectal tumors, in $30(86 \%)$ matching metastatic lymph nodes, in 34 (97\%) adjacent normal 
A

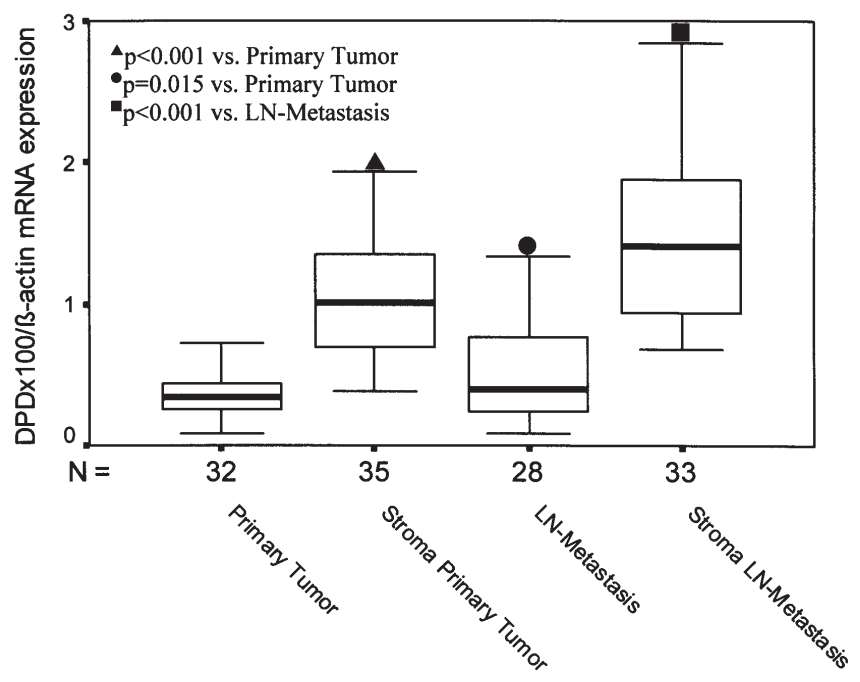

Histological Groups

B

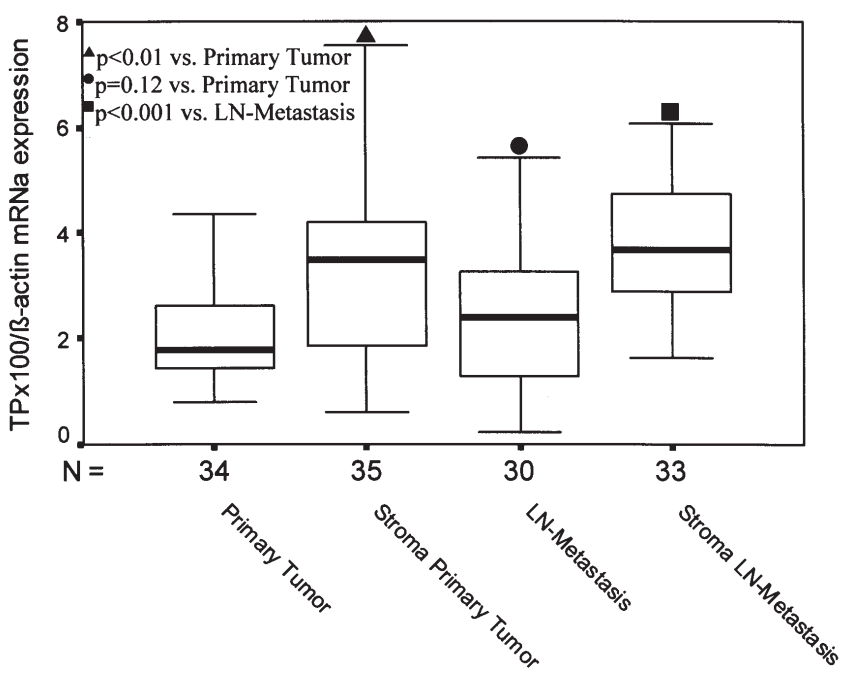

Histological Groups

C

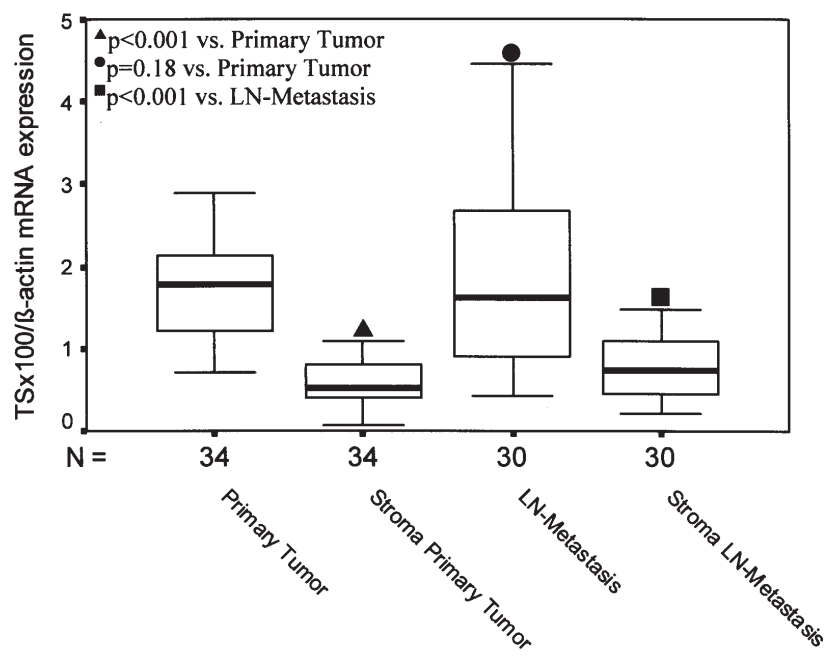

Histological Groups colon tissue samples and in $30(86 \%)$ adjacent normal lymph node tissue samples. The different ratios of quantifiable gene expression levels were based on the quality of cDNA.

Gene expression levels of DPD, TP and TS in the primary tumor and matching lymph node metastasis compared to normal adjacent tissue. The median gene expression levels and 25th/75th percentile of DPD, TP and TS are shown in Table II and Fig. 1. DPD and TP mRNA levels were significantly lower in the primary colorectal tumor compared with the normal adjacent stroma tissue $(\mathrm{p}<0.001 / \mathrm{p}<0.01)$, whereas TS mRNA levels were significantly higher in the primary tumor than in the normal adjacent tissue $(\mathrm{p}<0.001)$. The same relations were found in the metastatic lymph node metastases. DPD and TP gene expression levels again were lower in malignant tissue compared to the adjacent normal lymphatic tissue $(\mathrm{p}<0.001)$, whereas TS gene expression levels were significantly higher in the metastatic lymph node than in the adjacent normal stroma tissue of the lymph node $(\mathrm{p}<0.001)$.

Gene expression levels of DPD, TP and TS in the primary tumor compared to the matching lymph node metastasis. Gene expression levels of TP and TS did not differ significantly between primary colorectal tumor and matching lymph node metastasis $(\mathrm{p}=0.12, \mathrm{p}=0.18)$. Although the difference between the median DPD gene expression values was not large $(0.34$ vs. 0.39 , for primary and metastases, respectively, Table II), it was statistically significant that DPD gene expression levels in the lymph node metastases exceeded those in the matched primary colorectal tumors in a majority of cases $(17 / 27)(\mathrm{p}=0.015)$.

Correlation of DPD, TP and TS gene expression levels between the primary tumor and matching lymph node metastasis. There was a significant correlation for DPD, TP and TS gene expression levels between primary colorectal tumor and matched lymph node metastasis (DPD: $\mathrm{r}_{\mathrm{s}}=0.6, \mathrm{p}=0.001$; TP: $r_{s}=0.56, p=0.001 ;$ TS: $r_{s}=0.63, p<0.001 ;$ Fig. 2). In addition we found a significant correlation between DPD and TP in both primary tumor ( $\mathrm{rs}=0.4, \mathrm{p}=0.02)$ and lymph node metastases $\left(r_{s}=0.77, p<0.001\right)$, while no other significant correlation among the genes were detected.

\section{Discussion}

In this study, we have shown that the expressions of three genes relevant to 5-FU activity in tumors, TS, TP and DPD,

Figure 1. (A), Relative dihydropyrimidine dehydrogenase mRNA in the different histological groups. The boxes show the 25th and 75th percentile (interquartile) ranges. Median values are shown as a horizontal black bar in each box. The whiskers show levels outside the 25th and 75th percentile. (B), Relative thymidine phosphorylase mRNA in the different histological groups. The boxes show the 25th and 75th percentile (interquartile) ranges. Median values are shown as a horizontal black bar in each box. The whiskers show levels outside the 25th and 75th percentile. (C), Relative thymidylate synthase mRNA in the different histological groups. The boxes show the 25 th and 75 th percentile (interquartile) ranges. Median values are shown as a horizontal black bar in each box. The whiskers show levels outside the 25th and 75 th percentile. 
A

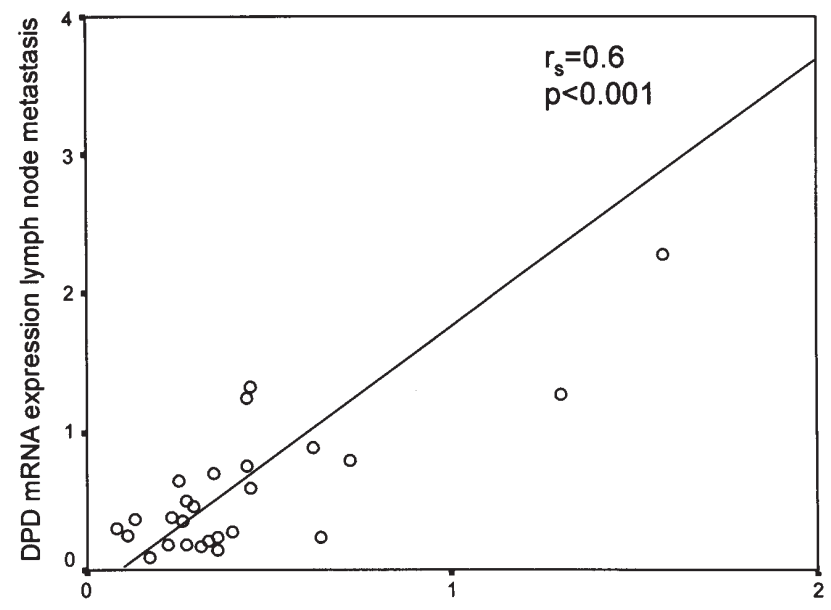

DPD mRNA expression primary tumor

B

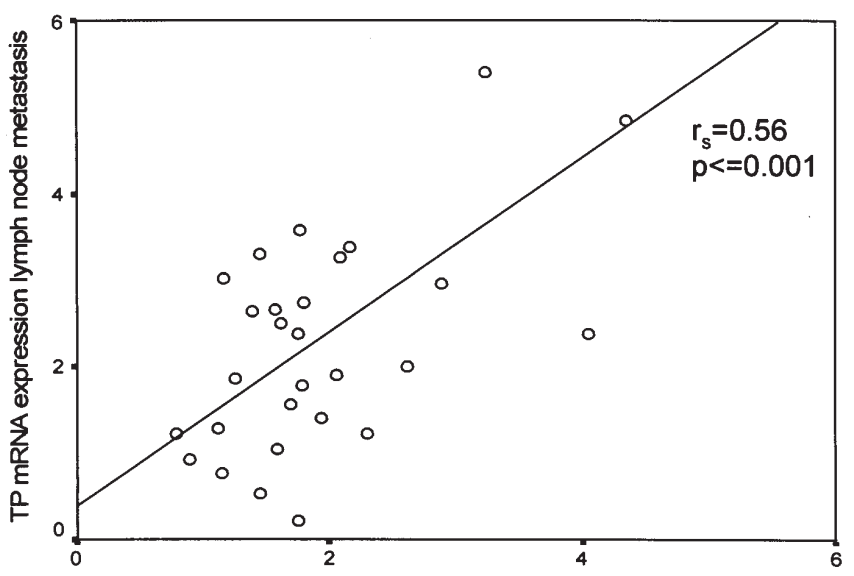

TP MRNA expression primary tumor

C

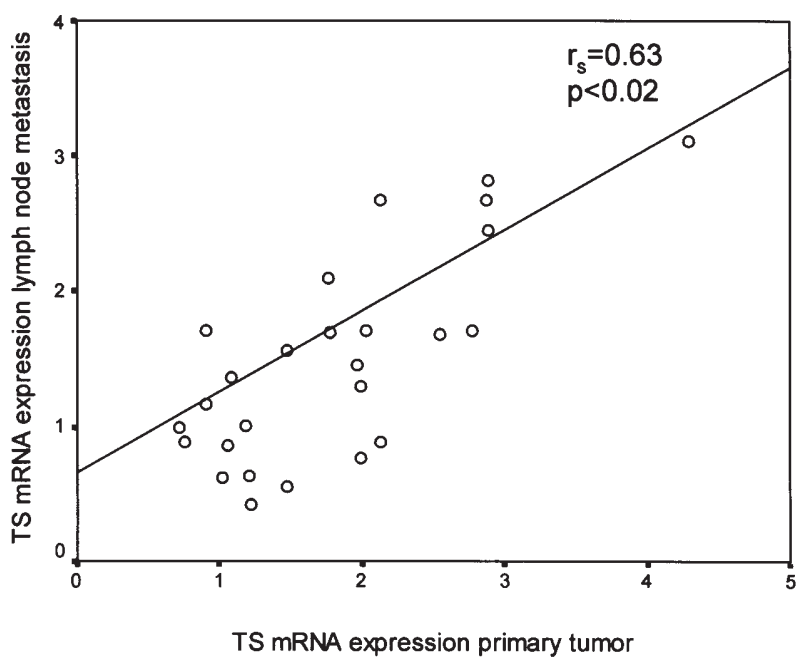

Figure 2. (A), Correlation of dihydropyrimidine dehydrogenase gene expression levels between the primary tumor and matching lymph node metastasis. (B), Correlation of thymidine phosphorylase gene expression levels between the primary tumor and matching lymph node metastasis. (C), Correlation of thymidylate synthase gene expression levels between the primary tumor and matching lymph node metastasis. are well preserved in tumor metastases to the lymph nodes. The expression values for TS and TP were not significantly different between primary tumor and lymph node metastases, although DPD expression in the lymph nodes somewhat exceeded those in the matched sets of primary tumors in the majority of cases. All three gene expressions showed a good positive correlation in the matched pairs of primary tumor and corresponding metastatic sites in the lymph nodes. This result is in contrast to several previously published studies which, as we discussed in the introduction section, reported or suggested a lack of correlation between TS and DPD expressions in primary tumor and matched sets of metastases. We think it is likely that, besides the common problem of small sample size (several studies had less than 10 metastases specimens), various technical and methodological issues could account in large part for these discrepant results. First, while we used RT-PCR to measure gene expressions (mRNA levels), some previous studies used IHC to measure TS, TP and DPD protein in primary tumor and metastatic tissue. IHC technology is semiquantitative with limited accuracy (e.g., staining scored as 'low, medium or high' or 'percent of positively staining cells/ total cells') and thus it would be difficult to obtain an accurate correlation coefficient between primary tumor and metastatic expressions, especially in studies with small numbers of samples. Different antibody preparations were used in some studies: those of Backus et al and Aschele et al, which reported no association of TS staining levels with tumor response, used TS polyclonal antibodies, while that of Paradiso et al, which reported that objective response to 5-FU did correlate with TS content, used monoclonal antibody TS106 (although, it should be noted, a later study by Johnston et al with TS 106 did not find primary tumor TS to be a predictive marker $(6,8,9,11)$. In short, there is a lack of standardization of procedures and validated quality control for these biomarker determinations. The effects of the use of different antibody preparations on the consistency of interobserver results have been well documented in the case of Her2 analyses (19).

In contrast to IHC, RT-PCR gives data in the form of numerical gene expression values and we have gone to considerable effort to validate the methodology in terms of designing the best primer sets and finding ranges of $\mathrm{Ct}$ values that are likely to give the most precise results. However, the use of RT-PCR for quantitative analysis of gene expression has its own set of pitfalls. First and foremost, since PCR is a homogeneous solution technology, the data will not truly reflect tumor gene expressions if the specimen from which the RNA is isolated contains appreciable amounts of nontumor tissue. All of the published studies to date appear to have used the specimens 'as is' without any particular postacquisition processing to separate tumor from non-tumor tissue. To deal with this problem, we performed careful LCM of the paraffin-embedded specimens and thus are able to claim with some degree of confidence that the specimens we analyzed all consisted of $>90 \%$ tumor or non-tumor tissue. Another issue is that gene expressions are reported as a ratio between the PCR products of the 'gene of interest' and an internal reference gene, which ideally is expressed at a constant level in the tissues being compared. However, two studies by Yamada and Inokuchi et al reporting varying 
results with respect to the relative median TS expressions in primary tumor and metastases used different reference genes for the PCR [glyceraldehyde-3-phosphate dehydrogenase (GAPDH) and $B$-actin, respectively], which may account for the discrepancies between these studies $(10,12)$.

It should be noted that whereas our present study examined gene expressions in lymph node metastases, some of the previous studies reporting lack of correlation between primary tumor and metastatic gene expressions used liver metastases for the comparison (12). It is possible that the situation with respect to preservation of gene expressions is different in tumor cells that have migrated to the liver than in those that have lodged in lymph nodes because of differences in microenvironment that could induce changes in genetic characteristics (20). This question is currently being addressed in our laboratory with another set of CRC tumor specimens and their corresponding liver metastases.

Since the LCM process was able to achieve a good separation of tumor tissue from stromal tissue in the specimens, we took the opportunity to compare gene expressions in these tissues. We found median TS expression to be higher in the tumor than stromal tissues and, as previously reported by Collie-Duguid et al, DPD to be higher in stromal than tumor tissues both in primary tumor and in the metastatic sites (21). However, our finding that median TP expression is higher in the stromal tissue than in the tumor tissue seems to contradict long-held prevailing notions about TP expression. In fact, the design of the 5-FU pro-drug Xeloda ${ }^{\circledR}$ (capecitabine) was based on the tenet that this drug should have greater specificity of action against tumors over normal tissue because TP, the enzyme that cleaves the compound to generate free 5-FU, was presumably expressed at a higher level in cancer cells, thereby preferentially giving rise to higher levels of 5-FU in tumor tissue (22). However, besides our data, the more recent literature also reveals some additional discrepant results regarding tumor/stromal TP expression. Whereas some studies did find higher expression of TP in primary tumor than in adjacent normal tissue (Fujiwaki et al; Hotta et al), others reported that TP protein was expressed mainly in stroma rather than in cancer tissue in uterine cervical cancer (Tang et al), in colorectal cancer (Saito et al) and prostate cancer (Okada et al) (23-27). These data suggest that the widely accepted idea that TP expression is generally elevated in tumor cells compared to non-tumor cells should be re-visited and may have to be revised.

Further statistical analysis of the data revealed a positive correlation between TP and DPD gene expressions in both primary tumor tissue and the lymph node metastases, suggesting a co-regulation of these two genes. The same observation was reported by Inokuchi et al in their study of gene expressions in primary CRC and liver metastases (12). Collie-Daguid et al previously suggested the presence of coordinated regulation of these pyrimidine metabolic enzymes (21).

In summary, the salient conclusion of this study is that if TS, TP and DPD gene expressions are response determinants of 5-FU based therapy, analysis of primary tumor tissue may provide a valid prediction of the effects of the treatment on lymph node metastases.

\section{References}

1. Grem JL: Intratumoral molecular or genetic markers as predictors of clinical outcome with chemotherapy in colorectal cancer. Semin Oncol 32: 120-127, 2005.

2. Leichman CG, Lenz HJ, Leichman L, Danenberg K, Baranda J, Groshen S, Boswell W, Metzger R, Tan M and Danenberg PV: Quantitation of intratumoral thymidylate synthase expression predicts for disseminated colorectal cancer response and resistance to protracted-infusion fluorouracil and weekly leucovorin. J Clin Oncol 15: 3223-3229, 1997.

3. Metzger R, Danenberg K, Leichman CG, Salonga D, Schwartz EL, Wadler S, Lenz HJ, Groshen S, Leichman L and Danenberg PV: High basal level gene expression of thymidine phosphorylase (platelet-derived endothelial cell growth factor) in colorectal tumors is associated with non-response to 5-fluorouracil. Clin Cancer Res 4: 2371-2376, 1998

4. Salonga D, Danenberg KD, Johnson M, Metzger R, Groshen S, Tsao-Wei DD, Lenz HJ, Leichman CG, Leichman L, Diasio RB and Danenberg PV: Colorectal tumors responding to 5-fluorouracil have low gene expression levels of dihydropyrimidine dehydrogenase, thymidylate synthase and thymidine phosphorylase. Clin Cancer Res 6: 1322-1327, 2000.

5. Park DJ, Stoehlmacher J and Lenz HJ: Tailoring chemotherapy in advanced colorectal cancer. Curr Opin Pharmacol 3: 378-385, 2003.

6. Paradiso A, Simone G, Petroni S, Leone B, Vallejo C, Lacava J, Romero A, Machiavelli M, De Lena M, Allegra CJ and Johnston PG: Thymidilate synthase and p53 primary tumor expression as predictive factors for advanced colorectal cancer patients. Br J Cancer 82: 560-567, 2000.

7. Findlay MP, Cunningham D, Morgan G, Clinton S, Hardcastle A and Aherne GW: Lack of correlation between thymidylate synthase levels in primary colorectal tumours and subsequent response to chemotherapy. Br J Cancer 75: 903-909, 1997.

8. Aschele C, Debernardis D, Tunesi G, Maley F and Sobrero A: Thymidylate synthase protein expression in primary colorectal cancer compared with the corresponding distant metastases and relationship with the clinical response to 5-fluorouracil. Clin Cancer Res 6: 4797-4802, 2000.

9. Johnston PG, Benson AB III, Catalano P, Rao MS, O'Dwyer PJ and Allegra CJ: Thymidylate synthase protein expression in primary colorectal cancer: lack of correlation with outcome and response to fluorouracil in metastatic disease sites. J Clin Oncol 21: 815-819, 2003.

10. Yamada H, Ichikawa W, Uetake H, Shirota Y, Nihei Z, Sugihara K and Hirayama R: Thymidylate synthase gene expression in primary colorectal cancer and metastatic sites. Clin Colorectal Cancer 1: 169-174, 2001.

11. Backus HH, van Groeningen CJ, Vos W, Dukers DF, Bloemena E, Wouters D, Pinedo HM and Peters GJ: Differential expression of cell cycle and apoptosis related proteins in colorectal mucosa, primary colon tumours and liver metastases. J Clin Pathol 55: 206-211, 2002.

12. Inokuchi M, Uetake H, Shirota Y, Yamada H, Tajima M and Sugihara K: Gene expression of 5-fluorouracil metabolic enzymes in primary colorectal cancer and corresponding liver metastasis. Cancer Chemother Pharmacol 53: 391-396, 2004.

13. Shirota Y, Ichikawa W, Uetake H, Yamada H, Nihei Z and Sugihara K: Intratumoral dihydropyrimidine dehydrogenase messenger RNA level reflects tumor progression in human colorectal cancer. Ann Surg Oncol 9: 599-603, 2002.

14. Guimbaud R, Guichard S, Dusseau C, Bertrand V, Aparicio T, Lochon I, Chatelut E, Couturier D, Bugat R, Chaussade S and Canal P: Dihydropyrimidine dehydrogenase activity in normal, inflammatory and tumour tissues of colon and liver in humans. Cancer Chemother Pharmacol 45: 477-482, 2000.

15. Marsh S, McKay JA, Curran S, Murray GI, Cassidy J and McLeod HL: Primary colorectal tumour is not an accurate predictor of thymidylate synthase in lymph node metastasis. Oncol Rep 9: 231-234, 2002.

16. Bonner RF, Emmert-Buck M, Cole K, Pohida T, Chuaqui R, Goldstein S and Liotta LA: Laser capture microdissection: molecular analysis of tissue. Science 278: 1481-1483, 1997.

17. Lord RV, Salonga D, Danenberg KD, Peters JH, De Meester TR, Park JM, Johansson J, Skinner KA, Chandrasoma P, De Meester SR, Bremner CG, Tsai PI and Danenberg PV: Telomerase reverse transcriptase expression is increased early in the Barrett's metaplasia, dysplasia, adenocarcinoma sequence. J Gastrointest Surg 4: 135-142, 2000. 
18. Heid CA, Stevens J, Livak KJ and Williams PM: Real-time quantitative PCR. Genome Res 6: 986-994, 1996.

19. Italian Network for Quality Assurance of Tumor Biomarkers (INQAT) Group: Interobserver reproducibility of immunohistochemical HER-2/neu evaluation in human breast cancer: the real-world experience. Int J Biol Markers 19: 147-154, 2004.

20. Kinzler K and Vogelstein B: Landscaping the cancer terrain. Science 279: 1036-1037, 1998.

21. Collie-Duguid ES, Johnston SJ, Boyce L, Smith N, Cowieson A, Cassidy J, Murray GI and McLeod HL: Thymidine phosphorylase and dihydropyrimidine dehydrogenase protein expression in colorectal cancer. Int J Cancer 94: 297-301, 2001.

22. Miwa M, Ura M, Nishida M, Swada N, Ishikawa T, Mori K, Shimma N, Umeda I and Ishitsuka H: Design of a novel oral fluoropyrimidine carbamate, caecitabine, which generates 5-fluorouracil selectively in tumours by enzymes concnetrted in human liver and cancer tissue. Eur J Biochem 34: 1274-1281, 1998.

23. Fujiwaki R, Hata K, Nakayama K, Fukumoto M and Miyazaki K: Gene expression for dihydropyrimidine dehydrogenase and thymidine phosphorylase influences outcome in epithelial ovarian cancer. J Clin Oncol 18: 3946-3951, 2000.
24. Hotta T, Taniguchi K, Kobayashi Y, Johata K, Sahara M, Naka T, Watanabe T, Ochiai M, Tanimura $\mathrm{H}$ and Tsubota YT: Comparative analysis of thymidine phosphorylase and dihydropyrimidine dehydrogenase expression in gastric and colorectal cancers. Oncol Rep 11: 1045-1051, 2004.

25. Tang W, Wang X, Utsunomiya H, Nakamuta Y, Yang Q, Zhang Q, Zhou G, Tsubota Y, Mabuchi Y, Li L and Kakudo K: Thymidine phosphorylase expression in tumor stroma of uterine cervical carcinomas: histological features and microvessel density. Cancer Lett 148: 153-159, 2000.

26. Saito S, Tsuno N, Nagawa H, Sunami E, Zhengxi J, Osada T, Kitayama J, Shibata Y, Tsuruo T and MutoT: Expression of platelet-derived endothelial cell growth factor correlates with good prognosis in patients with colorectal carcinoma. Cancer 88: $42-49,2000$

27. Okada K, Yokoyama K, Okihara K, Ukimura O, Kojima M, Miki T and Takamatsu T: Immunohistochemical localization of platelet-derived endothelial cell growth factor expression and its relation to angiogenesis in prostate. Urology 57: 376-381, 2001. 